\title{
KARAKTERISASI MINERAL IKUTAN TIMAH PADA ENDAPAN PRIMER, SEKUNDER, DAN TAILING DI BANGKA SELATAN DAN BELITUNG
}

\author{
Syafrizal $^{1)}$, Satyogroho Dian Amertho ${ }^{2)}$, Ichwan Azwardi ${ }^{2)}$, Teti Indriati ${ }^{1)}$, Amrita Oza \\ Nabilla $^{3)}$, Enrico Gilrandy Wahyu Suharjo ${ }^{3)}$ dan Arie Naftali Hawu Hede ${ }^{1)}$

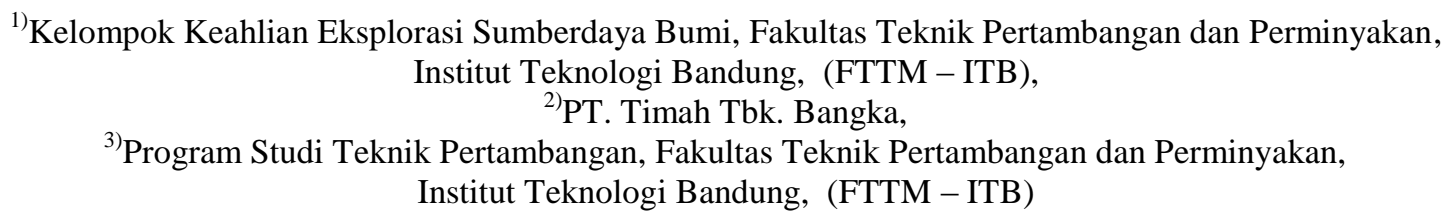

\begin{abstract}
ABSTRAK
Daerah Bangka Belitung termasuk dalam sabuk timah yang merupakan intrusi pluton granit. Selain merupakan pembawa logam timah, diketahui bahwa pada batuan granit juga merupakan batuan beku pembawa mineral-mineral Rare Earth Elements (REE) seperti monasit, dan xenotim. REE memiliki nilai ekonomis yang tinggi dan peran penting dalam perkembangan teknologi baru. Penelitian ini bertujuan untuk mengetahui kelimpahan kadar, mineralogi dan ukuran butir Mineral Ikutan Timah (MIT) pada endapan primer, sekunder, dan tailing di Bangka Selatan dan Belitung. Pengambilan sampel dilakukan secara acak (grab sampling) untuk sampel endapan aluvial, koluvial, tailing, serta konsentrat dan chip sampling untuk sampel endapan primer berbentuk batuan. Sampel dikeringkan menggunakan oven, kemudian direduksi menggunakan splitter hingga memperoleh volume sampel yang sesuai. Pengayakan sampel dilakukan menggunakan 5 (lima) fraksi yaitu \#+48, \#+65, \#+100, \#+150, dan \#-150 untuk memperoleh keseragaman butir sampel. Metoda analisis yang digunakan dalam penelitian ini adalah analisa radioaktif menggunakan scintillometer, mineral butir menggunakan metode grain counting, analisa mineragrafi dengan sayatan poles, serta analisa X-Ray Diffraction (XRD) berupa sampel bubuk.
\end{abstract}

Kata kunci : Mineral Ikutan Timah, Rare Earth Elements, Grain Counting, Monasit, Xenotim.

\begin{abstract}
The Bangka Belitung area is included in a tin belt which is an intrusion of granite pluton. Besides being a tin metal carrier, it is known that in granite rocks is also igneous rock carrying minerals Rare Earth Elements (REE) such as monasite, and xenotime. REE has high economic value and an important role in the development of new technologies. This study aims to determine the radioactive value, abundance of levels, mineralogy and size of associated tin minerals in primary, secondary and tailings deposits in South Bangka and Belitung. Sampling was carried out by grab sampling for alluvial, colluvial, tailing sediment samples, as well as concentrates and sampling chips for rock sediments. Sampling method by Random Sampling. The samples were dried using an oven, then reduced using a splitter to obtain the appropriate sample volume. Sifting the sample was carried out using 5 fractions namely \#+48, \#+65, \#+100, \#+150, and \#-150 to obtain uniformity of sample items. Radioactive analysis using scintillometers, grain minerals using the grain counting method, mineragraphy analysis with polish incisions, and X-Ray Diffraction (XRD) analysis in the form of powder samples.
\end{abstract}

Kata kunci : Mineral Ikutan Timah, Rare Earth Elements, Grain Counting, Monasit, Xenotim. 


\section{A. PENDAHULUAN}

Sabuk timah (Tin Belt) di Asia Tenggara memanjang lebih $3000 \mathrm{~km}$ dari Myanmar (Burma), Thailand, Malaysia, Singapura, dan Indonesia. Daerah Bangka Belitung termasuk dalam sabuk timah yang merupakan intrusi pluton granit. Selain merupakan pembawa logam timah, diketahui bahwa pada batuan granit juga merupakan batuan beku pembawa mineral-mineral Rare Earth Elements (REE) seperti monasit dan xenotim. Mineral pembawa REE biasanya terdapat sebagai mineral asosiasi dari komoditi utama endapan timah aluvial. Aktivitas dari pengolahan bijih timah seperti yang telah disampaikan sebelumnya akan menghasilkan tailing yang mungkin mengandung mineral pembawa REE. Kemungkinan REE yang terdapat dalam tailing memiliki karakteristik berbeda dari REE pada endapan primer dan sekunder.

Secara fisiografi Pulau Bangka merupakan pulau terbesar dalam Paparan Sunda (Sundaland) dan merupakan Sunda Peneplain, dicirikan oleh daerah berbukit dengan ketinggian batuan dasar yang membatasi Cekungan Sumatra Selatan di bagian timur dan Cekungan Sunda di bagian utara, Pulau Bangka termasuk Tin Islands, terletak pada Sundaland Craton Lempeng Eurasia (Barber, 2005).

Bila ditinjau dari sudut geologi, penyebaran bijih timah di Indonesia masih merupakan kelanjutan dari sabuk granit yang berumur Yura-Kapur yang membentang mulai dari Myanmar, Muangthai, Malaysia, Kepulauan Riau (Pulau Singkep, Pulau Karimun dan Pulau Kundur), Pulau Bangka dan Pulau Belitung hingga Pulau Karimata. Sabuk Granit sendiri merupakan deretan formasi batuan granit yang kaya akan mineral kasiterit, sehingga Pulau Bangka merupakan bagian Sabuk Timah Asia Tenggara (Cobbing, 2005).

Secara geologi, susunan batuan di Bangka Selatan paling muda yaitu endapan aluvium. Urutan batuan dari muda ke tua adalah; satuan endapan Aluvium (Qa), satuan batuan Formasi Ranggam (TQr), satuan batuan Formasi Tanjung Genting (Trt), Granit Klabat (TrJk), dan Kompleks Malihan Pemali (CPp), (Osberger, 1965). Peta Geologi yang mencakup daerah Bangka Selatan dapat dilihat pada Gambar 1.

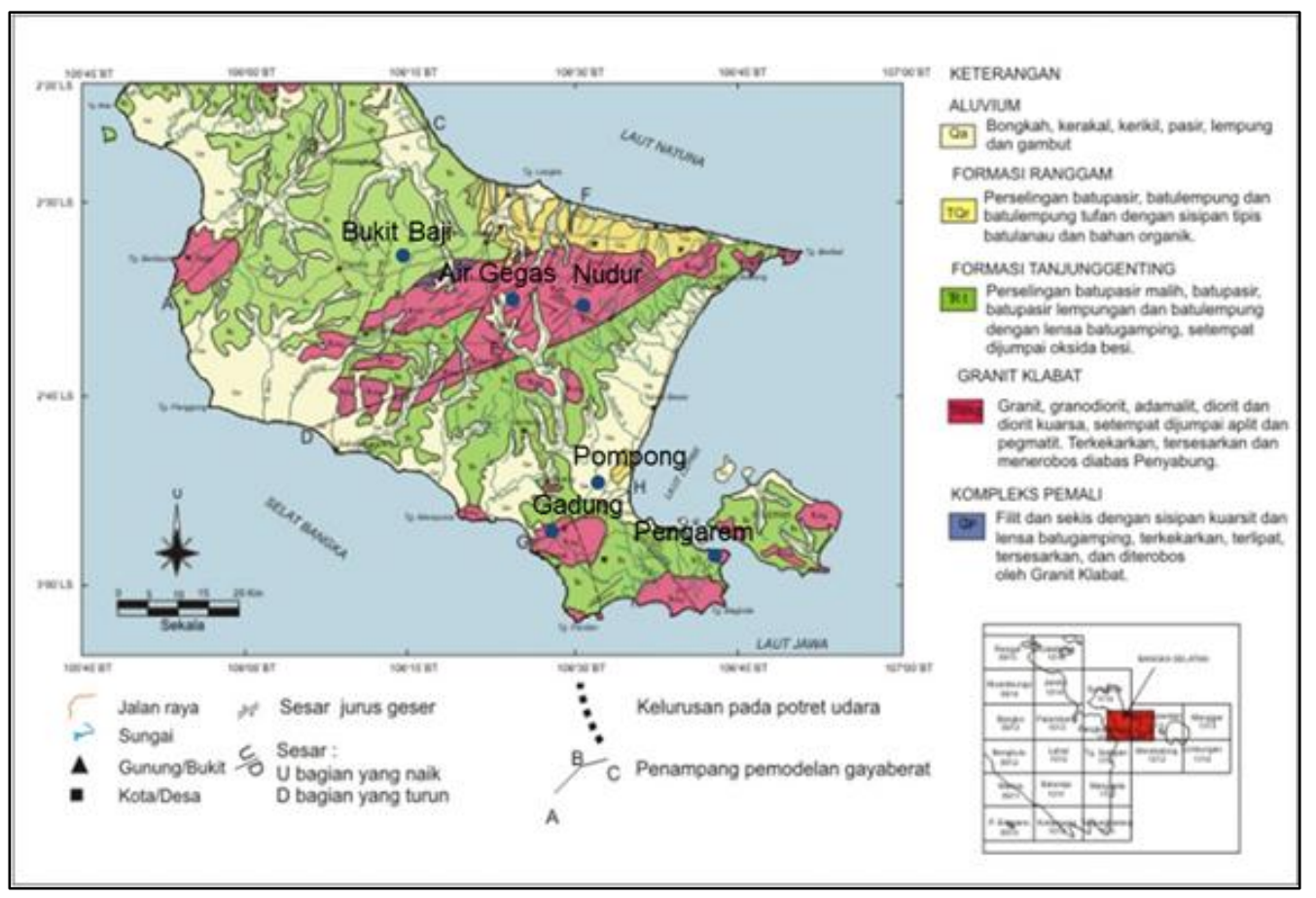

Gambar 1. Peta Geologi Bangka Selatan (dimodifikasi oleh Tatang Padmawajaya dari Margono, U. Supandjono, \& Partoyo, 1995). 
Sedangkan satuan formasi batuan yang ada di daerah Badau Belitung terdiri dari Formasi Kelapakampit (PCKs), Formasi Tajam (PCTm), Granit Tanjungpandan Pasir Berkarbon (Qpk) dan Endapan Aluvial dan Pantai (Qa). Area Granit Tanjungpandan merupakan host atau sumber bagi banyak konsentrasi kasiterit aluvial bernilai ekonomis yang terdapat di beberapa lembah besar dan salah satunya adalah Badau. Peta Geologi yang mencakup daerah Badau Belitung dapat dilihat pada Gambar 2.

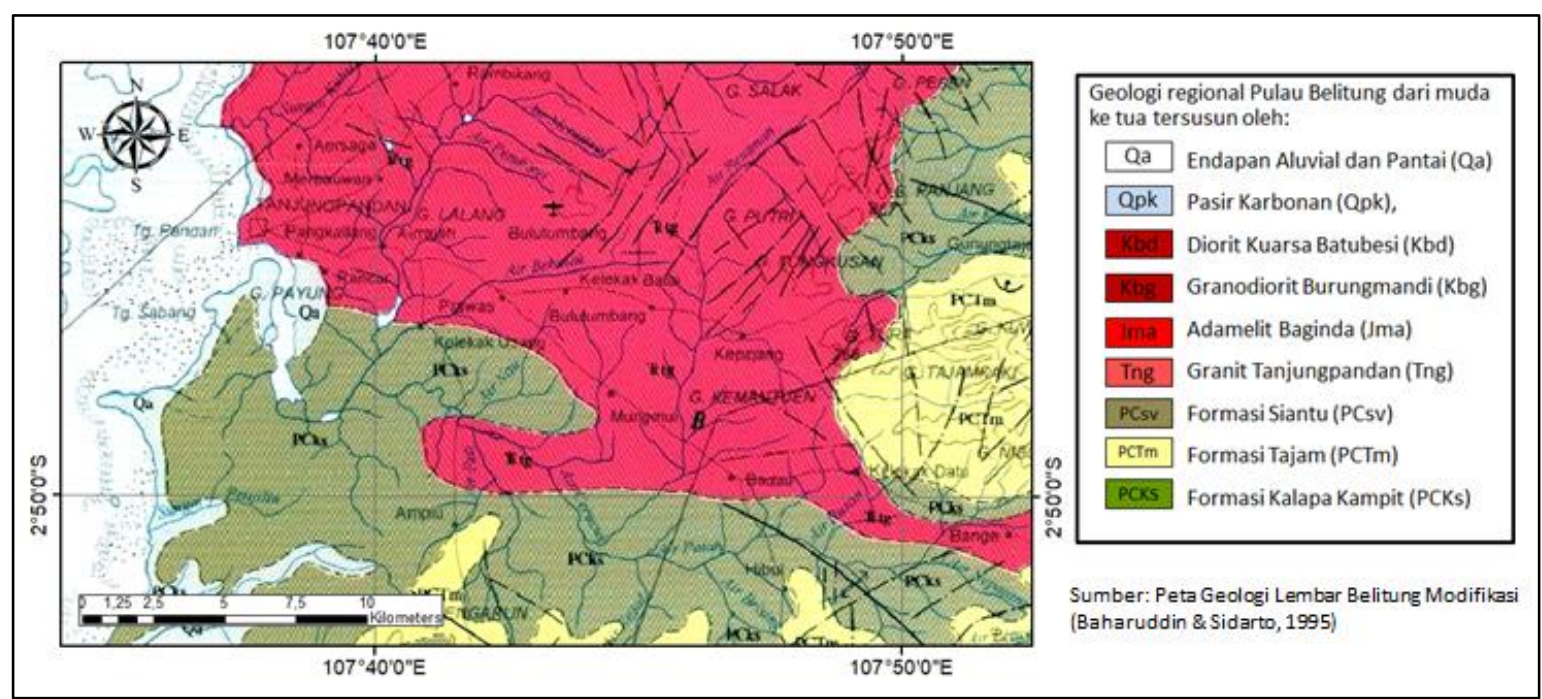

Gambar 2. Peta Geologi Badau dan sekitarnya, Belitung (dimodifikasi oleh Baharudin \& Sidarto, 1995).

REE memiliki nilai ekonomis yang tinggi dan berperan penting dalam perkembangan teknologi baru. Hal tersebut mendorong para peneliti untuk melakukan eksplorasi lebih mendalam tentang REE. Penelitian ini akan dilakukan untuk mempelajari karakteristik REE dari endapan timah primer, sekunder, dan tailing pada daerah Bangka Selatan di Provinsi Bangka Belitung. Unsurunsur dari kelompok (REE) terdapat pada mineral-mineral seperti monasit, zirkon, xenotim, ilmenit, rutil, dan lain-lain, yang merupakan mineral ikutan pada endapan timah dan disebut sebagai Mineral Ikutan Timah (MIT).

Pada endapan sekunder yang meliputi endapan eluvial, koluvial dan aluvial terjadi proses pengkayaan mineral-mineral berat seperti kasiterit dan MIT yang mengandung REE. Selain itu pada tailing/sisa pengolahan timah, MIT yang mengandung REE juga mengalami pengayaan relatif karena telah terpisah dari mineral kasiterit. Kehadiran mineral pembawa REE biasanya tidak lepas dari radioaktif. Unsur yang mengandung nilai radioaktif, sering dijumpai hadir bersamaan dengan mineral pembawa REE. Hal ini yang menyebabkan terdeteksinya mineral REE saat pengukuran dengan alat scintillometer untuk radioaktif.

Daerah Bangka Selatan yang terletak di Provinsi Kepulauan Bangka Belitung merupakan salah satu daerah penghasil timah yang potensi endapan MIT-nya belum dieksplorasi secara menyeluruh. Penelitian ini dilakukan sebagai tahap pendahuluan untuk dapat digunakan sebagai pembuka wawasan dan bahan pertimbangan dalam melakukan program eksplorasi pada endapan timah alluvial. 


\section{B. HASIL DAN PEMBAHASAN}

\section{B.1. Hasil dan Pembahasan Sampel Bangka Selatan}

Berdasarkan hasil nilai radioaktif sampel, diketahui bahwa terdapat berbagai macam variasi nilai pada sampel penelitian. Dari rekap hasil data penelitian sampel, didapatkan pengukuran tertinggi nilainya ada pada fraksi \#48 dan \#100, sedangkan paling kecil nilainya pada fraksi \#-150.

Berdasarkan hasil analisis sampel dengan metode mineral butir, dari kelima cluster tersebut dapat diketahui bahwa pada sampel konsentrat memiliki kadar kasiterit, monasit, zirkon, dan xenotim paling tinggi. Hal ini dikarenakan lokasi pengambilan sampel merupakan tempat pengolahan menjadi konsentrat (mineral berharga) sehingga kadarnya cukup tinggi. Sedangkan mineral ilmenit tertinggi ada pada sampel aluvial. Mineral rutil hanya ditemui pada beberapa sampel, dan yang paling tinggi berada pada sampel koluvial. Dapat diketahui bahwa kehadiran mineral ikutan timah seperti monasit, zirkon, dan xenotim, bersamaan dengan kehadiran mineral kasiterit yang merupakan mineral pembawa timah.

Analisis mineragrafi dilakukan pada 5 sampel sayatan poles yang masing-masing mewakili cluster sampel endapan primer, aluvial, koluvial, tailing dan konsentrat. Sayatan poles yang dilakukan diambil dari sampel pada fraksi \#100, karena setelah dilakukan analisis radioaktif dan mineral butir, diketahui bahwa banyaknya variasi mineral ikutan timah berada pada fraksi \#100. Hasil menunjukkan bahwa mineral yang teramati pada sampel sayatan poles yaitu kasiterit, ilmenit, monasit, xenotim, zirkon, kuarsa, hematit, dan rutil. Hal tersebut mirip dengan hasil pengamatan dengan mineral butir.

Analisis ini dilakukan pada 2 sampel yang tidak dapat dilakukan mineralogi butir karena berbentuk serbuk, sehingga untuk mengetahui kandungan mineral pada sampel ini dilakukan analisis XRD. Sampel tersebut berasal dari sampel endapan primer daerah Pengarem dengan kode PGM_PR, dan berasal dari tailing daerah Gadung. Berdasarkan hasil XRD, mineral yang terdapat pada sampel yaitu zirkon, ilmenit, monasit, xenotim, dan rutil (Gambar 3). Mineral zirkon yang paling mendominasi.

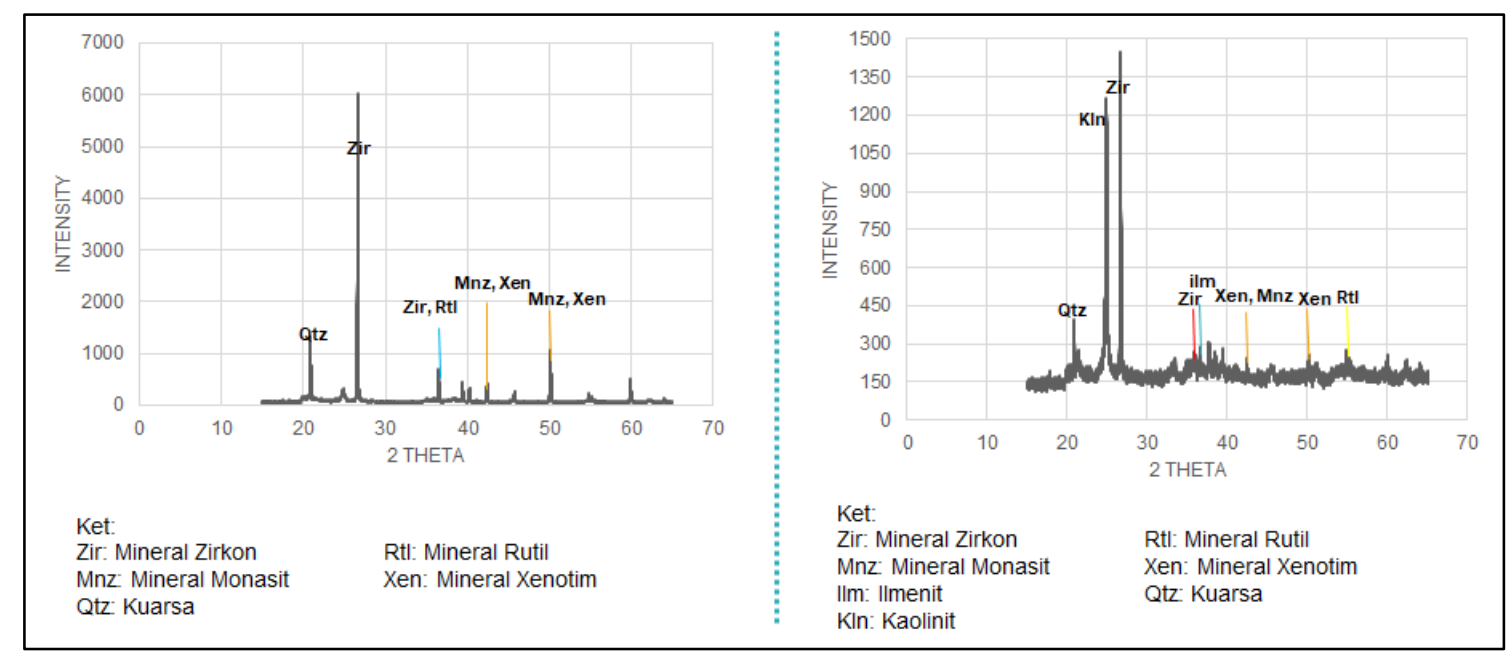

Gambar 3. Difraktogram hasil pengukuran XRD sampel Bangka Selatan

\section{Karakteristik Sampel Endapan Primer.}

Berdasarkan hasil pengukuran dengan scintillometer pada semua sampel endapan primer, nilai radioaktif rata-rata tertinggi ada pada fraksi \#150, dan yang terendah ada pada fraksi \#-150. Nilai radioaktif tertinggi adalah $11,7 \mu \mathrm{rt} / \mathrm{hr}$ yaitu pada sampel berupa singkapan batuan granit primer dari daerah Gadung. Nilai radioaktif ini berkorelasi dengan hasil grain counting yang menunjukkan 
kehadiran mineral seperti monasit, zirkon, dan xenotim pada fraksi tersebut, dengan mineral zirkon paling tinggi kadarnya. Zirkon memiliki sifat resisten yang tinggi, dengan ukuran butir yang kecil sehingga memungkinkan apabila kehadirannya banyak ditemui bersamaan dengan mineral pembawa timah. Bentuk butir pada masing-masing mineral sampel ini euhedral hingga anhedral (angular). Hasil XRD sampel endapan primer juga menunjukkan bahwa MIT yang signifikan adalah zirkon.

\section{Karakteristik Sampel Endapan Aluvial}

Berdasarkan hasil pengukuran dengan scintillometer pada semua sampel endapan aluvial, nilai radioaktif rata-rata tertinggi ada pada fraksi \#+65, dan yang terendah ada pada fraksi \#+150 dan \#150. Nilai radioaktif tertinggi adalah $12,3 \mu \mathrm{rt} / \mathrm{hr}$ yaitu sampel berupa material loose dari daerah Nudur. Nilai radioaktif ini berkorelasi dengan hasil analisis grain counting pada fraksi tersebut yang menunjukkan kadar mineral tanah jarang (monasit, zirkon, dan xenotim) yang signifikan, dan juga kadar mineral bijih titanium ilmenit yang paling tinggi. Bentuk butir zirkon dan ilmenit menunjukkan euhedral hingga anhedral, sedangkan mineral lain umumnya berbentuk subangular hingga subrounded.

\section{Karakteristik Sampel Endapan Koluvial}

Berdasarkan hasil pengukuran dengan scintillometer pada semua sampel endapan koluvial, nilai radioaktif rata-rata tertinggi ada pada fraksi \#+100, dan yang terendah ada pada fraksi \#-150. Nilai radioaktif tertinggi adalah $11,4 \mu \mathrm{rt} / \mathrm{hr}$ yaitu sampel berupa material bongkah dari daerah Pompong. Nilai radioaktif ini berkorelasi dengan hasil grain counting yang menunjukkan kehadiran mineral seperti monasit, zirkon, dan rutil pada fraksi tersebut, dengan mineral rutil paling tinggi kadarnya. Bentuk butir pada masing-masing mineral sampel penelitian yaitu subangular.

\section{Karakteristik Sampel Tailing}

Berdasarkan hasil pengukuran dengan scintillometer pada semua sampel tailing, nilai radioaktif rata-rata tertinggi ada pada fraksi \#+48, dan yang terendah ada pada fraksi \#-150. Nilai radioaktif tertinggi adalah $11,7 \mu \mathrm{rt} / \mathrm{hr}$ yaitu sampel berupa material loose dari daerah Pompong. Namun, nilai radioaktif ini tidak berkorelasi dengan kehadiran mineral tanah jarang. Mineral yang teridentifikasi pada analisis grain counting fraksi \#+48 ini hampir seluruhnya kuarsa. Tingginya nilai radioaktif pada sampel berukuran kasar ini, diduga karena adanya inklusi mineral pembawa unsur tanah jarang/unsur radioaktif yang berukuran sangat halus di dalam kuarsa. Bentuk butir mineral kuarsa yaitu subrounded hingga rounded.

Hasil XRD pada serbuk sampel tailing menunjukkan keterdapatan MIT yaitu zirkon, monasit, xenotim, rutil, yang didominasi oleh zirkon (lihat Gambar 3).

\section{Karakteristik Sampel Konsentrat}

Berdasarkan hasil pengukuran dengan scintillometer pada semua sampel konsentrat, nilai radioaktif rata-rata tertinggi ada pada fraksi \#+100, dan yang terendah ada pada fraksi \#-150. Nilai radioaktif tertinggi adalah $28,8 \mu \mathrm{rt} / \mathrm{hr}$ yaitu sampel konsentrat midling bijih kasiterit produk konsentrasi mejagoyang kering pada PPBT. Nilai radioaktif berkorelasi dengan hasil grain counting yang menunjukkan kehadiran mineral seperti monasit, ilmenit, zirkon, dan xenotim pada fraksi tersebut, yang kadarnya tinggi, dengan mineral zirkon paling dominan.

\section{B.2. Hasil dan Pembahasan Sampel Badau Belitung}

\section{Analisis Makroskopis Granit}

Sampel primer yang berupa batuan yang telah diambil dari lapangan dideskripsi secara makroskopis dan diklasifikasikan berdasarkan IUGS (International Union of Geological Science) dan penelitian yang telah dipublikasi oleh Schwartz dan Surjono (1990). Hasil pengamatan atau deskripsi sampel primer berdasarkan IUGS dapat disimpulkan bahwa semua sampel merupakan 
batuan granit. Namun, pengklasifikasian lebih detail menurut Schwartz dan Surjono (1990) menunjukkan bahwa sampel merupakan Megacrystic medium-grained biotite Granite dan Muscovitized megacrystic medium-grained Granite.

\section{Analisis Scintillometer}

Berdasarkan pengukuran yang dilakukan pada masing-masing jenis sampel, terlihat tidak ada perubahan yang signifikan antara sampel primer sampai dengan sampel SHP Lobi. Namun, perubahan nilai yang signifikan terjadi di sampel konsentrat. Perubahan nilai intensitas radiasi yang semula berada pada nilai 10.4 - $11.53 \mu$ rontgen/hour, berubah menjadi $22.37 \mu$ rontgen/hour. Hal ini dikarenakan terjadi pengkayaan monasit pada sampel konsentrat.

\section{Analisis Grain Counting}

Kemampuan mengidentifikasi mineral-mineral ikutan timah merupakan kemampuan yang paling mendasar dan penting dalam melakukan analisis Grain Counting. Kesalahan dalam membedakan mineral berpengaruh terhadap perhitungan kadar. Analisis grain counting untuk menghitung kadar MIT dilakukan terhadap tiga fraksi mineral butir yaitu fraksi \#48, \#65 dan \#100. MIT sampel aluvial terbanyak berada pada fraksi \#65 (8.98\%) dengan kehadiran MIT zirkon ( $\mathrm{N}=19$ sampel; mean $=3.29 \%$; range $=0.29 \%-10.42 \%$ ). MIT sampel SHP terbanyak berada pada fraksi \#65 $(8.27 \%)$ dengan kehadiran MIT zirkon $(\mathrm{N}=10$ sampel; mean $=3.25 \%$; range $=0.34 \%-6.11 \%)$. MIT sampel konsentrat terbanyak berada pada fraksi \#65 (39,87\%) dengan kehadiran MIT ilmenit $(\mathrm{N}=4$ sampel; mean $=24.61 \%$; range $=2.59 \%-46.33 \%)$.

\section{Analisis Mineragrafi Granit dan MIT}

Analisis mineragrafi pada sampel granit dilakukan untuk mengetahui tipe dari granit. Salah satu perbedaan mencolok antara granit tipe-I dan tipe-S adalah bahwa biotit pada granit tipe-S biasanya bersifat pleokroisme dengan warna merah-coklat, sedangkan pada granit tipe-I menunjukkan penyerapan yang lebih kuat dan pleokroisme dari coklat hingga kuning jerami atau strawcoloured (Chappell \& White, 2001). Sayatan yang digunakan hanyalah sayatan tipis (thin section) karena biotit (mineral target yang menjadi pembeda dari tipe granit) memiliki sifat transparan sampai semi transparan.

Pada sayatan poles, mineral monasit memiliki warna abu-abu kekuningan, tidak memiliki pleokroisme mau pun bireflektan. Monasit memiliki bentuk atau habit subhedral dan belahan (cleavage) yang tidak jelas. Pada pengamatan Nikol Silang, monasit menunjukkan sifat isotropi sehingga tidak memiliki warna interferensi. Salah satu ciri optik yang paling menonjol dari monasit, memiliki refleksi dalam (Internal Reflection) yang berwarna kuning terang sampai putih. Sedangkan, ilmenit memiliki reflektansi paling besar di antara mineral monasit dan zirkon. Warna reflektansi yang ditunjukkan oleh ilmenit adalah abu-abu keputihan (terang) yang memiliki bireflektansi yang tidak terlalu jelas dengan perubahan warna abu-abu hitam (gelap). Ilmenit memiliki habit euhedral serta tidak menunjukkan belahan. Ilmenit pada pengamatan Nikol Silang memperlihatkan sifat anisotropi lemah. Ilmenit tidak memiliki warna refleksi dalam karena ilmenit merupakan mineral opak. Zirkon pada pengamatan Nikol Sejajar memperlihatkan warna bau-abu sedang atau dalam kata lain memiliki warna reflektansi paling rendah di antara monasit dan ilmenit. Pleokroisme mau pun bireflektansi pada zirkon tidak terlihat. Zirkon memiliki belahan satu arah yang tidak terlalu jelas. Pada pengamatan Nikol Silang, Zirkon menujukkan sifat isotrop. Sama halnya dengan monasit, zirkon memiliki ciri yang menonjol yaitu memperlihatkan refleksi dalam dengan warna putih-transparan

Berbeda dengan pengamatan pada sayatan poles, pada sayatan tipis, mineral monasit justru menunjukkan kenampakkan warna kuning-putih. Hal yang paling terlihat beda, monasit pada pengamatan sayatan poles dan tipis terletak pada pengamatan Nikol Silang. Monasit menunjukkan sifat anistrop dengan warna merah-hijau. Ilmenit justru tidak menunjukkan karakteristik yang unik yang dapat diamati pada sayatan tipis. Warna yang ditunjukkan adalah hitam (opak) dengan bentuk anhedral dan sifat isotropi pada pengamatan Nikol Silang. 


\section{Analisis X-ray Diffraction (XRD)}

Hasil analisis XRD menunjukkan kehadiran mineral kuarsa dan serisit (mineral penciri endapan Greisen) yang konsisten di setiap sampel primer, eluvial, koluvial, aluvial dan SHP. Namun, untuk sampel aluvial tidak ditemukan kehadiran mineral serisit dan kehadiran kaolinit yang dominan. Hal ini dikarenakan sampel tersebut merupakan sampel batuan granit yang terlapukan (clay). Hasil analisis XRD juga terbukti bahwa sampel konsentrat merupakan konsentrat ilmenit dan monasit beserta MIT lainnya (Gambar 4).

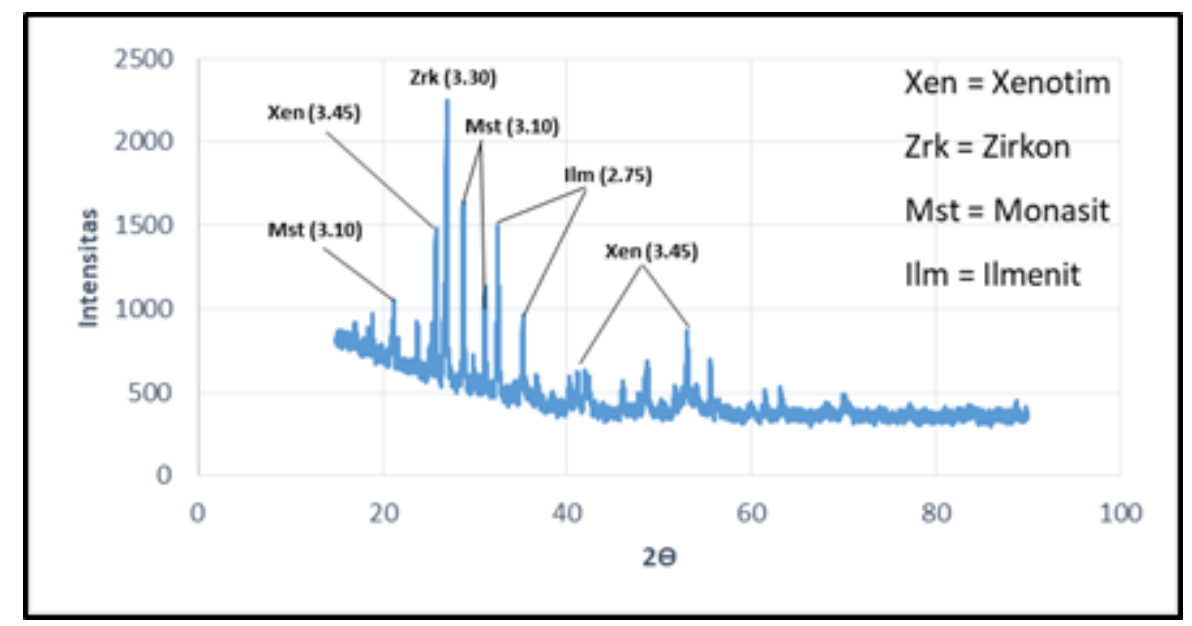

Gambar 4. Difraktogram hasil pengukuran XRD sampel Badau Belitung.

\section{Diskusi}

Keterdapatan MIT tidak ditemukan pada sampel primer, eluvial dan koluvial. Sulit untuk memperoleh MIT pada sampel primer, eluvial, koluvial atau batuan dikarenakan MIT hadir dalam bentuk disseminated (butiran-butiran yang saling menyebar). Selain itu, MIT pada batuan hadir sebagai mineral trace atau mineral aksesoris. Kondisi serupa diverikasi pada analisis XRD. Hasil XRD pada sampel primer tidak menunjukkan keterdapatan MIT. Hal ini dapat terjadi dikarenakan XRD hanya dapat membaca mineral yang memiliki \% kadar tinggi (> 2\%). Oleh karena itu, kemungkinan MIT pada sampel primer hadir dalam \% kadar yang sangat rendah karena MIT merupakan mineral trace atau mineral aksesoris.

Berbeda dengan sampel primer, MIT pada sampel aluvial, SHP mau pun konsentrat hadir dalam butiran-butiran lepas yang telah tertransportasi. Kehadiran mineral monasit, ilmenit, xenotim, dan zirkon pada sampel mineral butir seperti aluvial, SHP dan konsentrat dibuktikan dengan analisis Grain Counting. MIT pada sampel aluvial memiliki sortasi yang baik dengan bentuk butir dari menyudut hingga membundar. Begitu pun dengan MIT pada sampel SHP memiliki bentuk butir menyudut dan membundar dengan sortasi yang moderat atau sedang hingga baik dikarenakan SHP dapat bersumber dari sampel dan tempat mana saja. Pada sampel SHP, zirkon hadir dalam ukuran yang paling kecil di antara MIT lainnya. Sedangkan pada sampel konsentrat, MIT memiliki bentuk butir yang cenderung membundar dengan sortasi yang sangat baik dan untuk zirkon tetap memiliki karakteristik pertumbuhan yang paling kecil di antara MIT lainnya karena ketika berada di primer/sumber, biasanya zirkon hadir dalam bentuk inklusi fluida. Selain karakteristik yang disebutkan di atas, berdasarkan analisis Scintillometer, monasit merupakan MIT yang memiliki sifat radioaktif.

Fakta, keterdapatan MIT yang merupakan mineral target tidak selalu ditemukan di setiap jenis sampel, bahkan untuk mineral anatase dan rutil tidak ditemukan satu pun pada setiap jenis sampel. Hal ini diduga karena tidak adanya sumber dari anatase dan rutil serta densitas dari mereka yang 
lebih rendah dibandingkan dengan MIT lain sehingga kehadiran mereka tidak bersama-sama dengan MIT yang lain.

Dalam teori sederhana, mineral-mineral yang memiliki densitas yang sama akan terendapkan bersama-sama pada lingkungan yang sama. Seperti monasit, ilmenit, zirkon dan xenotim ditemukan pada sampel aluvial, SHP dan konsentrat dikarenakan memiliki densitas yang sama. Hal ini yang membuat keberadaan mereka bersama-sama. Lebih lanjut lagi, ukuran butir juga berpengaruh dalam proses pengendapan MIT pada suatu lingkungan. Hubungan antara ukuran butir dan densitas diwujudkan dalam suatu teori nisbah pengendapan (settling ratio).

Keberadaan REE yang merupakan bahan baku untuk industri masa kini, ternyata berasosiasi dengan batuan granit (Setijadji, 2011). Karakteristik granit beperan penting dalam penentuan sumber atau hulu dari REE yang ada pada MIT. Analisis makroskopis baik menurut IUGS mau pun Schwartz dan Surjono (1990) menyatakan bahwa semua sampel primer merupakan batuan granit. Oleh karena itu, dapat diindikasikan bahwa semua batuan granit yang ada di daerah penelitian merupakan sumber dari MIT. Namun, Chappell \& White (2001), dalam jurnal publikasinya yang berjudul: "Two Contrasting Granite Types: 25 Years Later" membagi granit dalam dua tipe yaitu tipe-I dan tipe-S dan menyatakan bahwa granit yang berasosiasi dengan mineral ilmenit adalah granit tipe-S. Teori sejalan dikemukakan juga oleh Bemmelen (1949) bahwa granit tipe-S diketahui berasosiasi dengan timah, besi, bauksit serta tungsten, lantanida, cerium, neodimium dan REE lain. Salah satu metode penentuan tipe granit yang digunakan adalah petrografi. Oleh karena itu, dapat diindikasikan bahwa sumber dari REE adalah granit yang berada di bukit intrusi bagian dari formasi Granit Tanjungpandan.

Genesa MIT yang ada di Kecamatan Badau merupakan tipe letakan (sekunder) sebagai hasil proses rombakan dan sedimentasi. menunjukkan sketsa dari genesa MIT di mana MIT bersumber dari bukit intrusi formasi Granit Tanjungpandan yang mengalami rombakan atau erosi tertransportasi oleh gravitasi sehingga hanya berada di sekitar lereng bukit. Fase ini disebut eluvial. Kemudian, MIT mengalir menuruni bukit akibat tertransportasi oleh air namun peran air masih sangat kecil sehingga MIT belum sampai pada badan atau daerah sungai yang kemudian fase ini disebut fase koluvial. Selanjutnya, MIT tertransportasi kembali oleh air hingga sampai pada badan sungai kemudian tertransportasi mengikuti arah aliran sungai (sungai purba) dan terendapkan pada satu waktu dan tempat akibat faktor densitas yang dinamakan fase fluvial (aluvial). MIT yang tidak terendapkan akan tertransportasi sampai pada hilir sungai yaitu pantai. MIT terbawa sampai melebihi bibir pantai dan kemudian terdorong oleh ombak pantai sehingga terendapkan di bibir pantai. Fase ini dinamakan fase endapan pantai (aluvial) dan menjadi fase terakhir dari genesa MIT.

\section{KESIMPULAN}

Pada Sampel Bangka Selatan menunjukkan bahwa :

a. Nilai radioaktif tertinggi dijumpai pada cluster sampel konsentrat, yang berkorelasi dengan MIT pembawa unsur tanah jarang, yaitu monasit dan zirkon yang tinggi.

b. Jenis MIT yang kadarnya paling tinggi pada semua cluster sampel yaitu zirkon.

c. Kadar ilmenit yang paling tinggi dijumpai pada cluster sampel endapan aluvial.

d. Mineral rutil hanya dijumpai pada cluster sampel endapan aluvial, koluvial dan tailing, sedangkan xenotim ada pada semua cluster dengan jumlah yang sedikit.

e. Bentuk butir sampel dari cluster endapan primer hingga tailing yaitu angular hingga rounded.

Pada Sampel Badau Belitung menunjukkan bahwa :

a. MIT berupa monasit, zirkon, xenotim, ilmenit terdapat pada sampel aluvial, SHP dan konsentrat. Sedangkan untuk mineral rutil dan anatase tidak ditemukan pada sampel apa pun. Sampel primer, eluvial dan koluvial tidak menunjukkan keberadaan MIT. 
b. MIT pada sampel aluvial berbentuk butiran lepas dengan bentuk butir menyudut hingga membundar dan sortasi yang baik. Selanjutnya, pada sampel SHP, MIT berbentuk butiran lepas dengan bentuk butir menyudut hingga membundar dengan sortasi moderat (sedang). Sedangkan, pada sampel konsentrat MIT memiliki bentuk butir yang cenderung membundar dengan sortasi yang sangat baik. Zirkon hadir dalam bentuk ukuran kristal paling kecil. Monasit merupakan satu-satunya MIT yang memiliki sifat radioaktif.

c. Indikasi sumber atau hulu dari MIT atau REE yang terdapat di Kecamatan Badau, Kabupaten Belitung, Provinsi Kepulauan Bangka Belitung adalah batuan granit dengan tipe-S yaitu bukit intrusi dari formasi Granit Tanjungpandan.

\section{DAFTAR PUSTAKA}

Barber. (2005). Tectonic Evolution. In A. J. Barber, M. J. Crow, \& J. S. Milsom, Sumatra: Geology, Resources and Tectonic Evolution (pp. 234-257). Geological Society Memoar.

Cobbing, E. J. (2005). Granite. In B. A. J, C. M. J, \& M. and J.S, Sumatra: Geology, Resources and Tectonic Evolution (p. 31). Geological Society Memoir.

Crow. (2005). Pre-Tertiary Volcanic Rocks. In Barber, Crow, \& Milsom, Sumatra: Geology, Resources and Tectonic Evolution (p. 31). Geological Society Memoir.

Margono, U.Supandjono, R., \& Partoyo, d. E. (1995). Peta Geologi Lembar Bangka Selatan. Bandung: Puslitbang Geologi.

Osberger. (1965). Geology of Bangka. Mining Geology Note, 36.

Adam, J. W. (1960). On the Geology of the Primary Tin-ore Deposits in the Sedimentary Formation of Billiton. Geologic Mijnb Vol. 39, 405-426.

Aleva, G. J. (1960). The Plutonic Igneous Rocks from Billiton, Indonesia. Geologic Mijnb Vol. 39, 427-436.

Badan Pusat Statistik Kabupaten Belitung. (2018). Kabupaten Belitung Dalam Angka 2018. Tanjungpandan: BPS Kabupaten Belitung.

Baharuddin, \& Sidarto. (1995). Peta Geologi Lembar Belitung, Sumatera. Bandung: Pusat Penelitian dan Pengembangan Geologi.

Bemmelen, R. W. (1949). The Geology of Indonesia, Vol IA, General Geology of Indonesia and Adjacent Archipelagoes. The Hague: Martinus Njhoff.

Best, M. G. (2003). Igneous and Metamorphic Petrology. UK: Blackwell Publishing.

Binder, H. H. (1999). Lexikon der chemischen Elemente. Das Periodensystem in Fakten, Zahlen und Daten. Stuttgart: Hirzel.

Cahyo, F. A. (2015). Rare Earth Mineral (REE): Masa Depan Endapan. Geopangea Research Group Indonesia.

Chappell, B. W., \& White, A. J. (2001). Two Contrasting Granite Types: 25 Years Later. Australian Journal of Earth Sciences, 489-499.

Evans, A. M. (1987). Ore Geology and Industrial Minerals: An Introduction. UK: Blackwell.

Gill, R. (2010). Igneous Rocks and Processes: A Practical Guide. UK: Blackwell.

Haxel dkk. (2005). Rare Earth Elements - Critical Resources for High. US Geological Survey.

Inatadon, N. F., Abdurrachman, M., \& Aziz, M. (2015). Geologi dan Studi Logam Tanah Jarang Daerah Kacang Butor dan Sekitarnya, Kecamatan Badau, Kabupaten Belitung, Provinsi Kepulauan Bangka Belitung. Seminar Nasional Kebumian Ke-8 (pp. 744-753). Yogyakarta: Academia-Industry Linkage.

Jones dkk. (1977). Age of Tin Mineralization and Plumboteetonies, Belitung, Indonesia. ECON. GEOL Vol. 72, 745-752.

Lehmann, R., \& Harmanto. (1990). Large-scale Tin Depletion in the Tanjungpandan Tin Granite, Belitung Island. ECON. GEOL Vol. 85, 99-111.

Lubis, I. A. (2017). Teknik Penambangan Timah Alluvial. PT TIMAH.

Osberger, R. (1962). Geologi dari Pulau Belitung. Arnhem, Netherlands, Billiton Co., Unpub rept., 160.

Pearce, J. (1996). Sources and Setting of Granitic Rocks. Episodes, Vol. 19/4, 120-125. 
Priem dkk. (1975). Isotope Geochronology in the Indonesian Tin Belt. Geologie Mijnb Vol. 54, 6170.

Raymond, L. A. (2002). The Study of Igneous, Sedimentary, and Metamorphic Rocks. New York: McGraw-Hill.

Rohmana, \& Tain, Z. (2006). Inventarisasi Bahan Galian pada Wilayah PETI Daerah Kampar, Provinsi Riau. Bandung: Pusat Sumber Daya Geologi.

Rollinson, H. R. (1993). Using Geochemical Data: Evaluation, Presentation, Interpretation. England: Pearson Education Limited.

Schwartz, M. O., \& Surjono. (1990). Greisenization and Albitization at the Tikus Tin-Tungsten Deposit, Belitung, Indonesia. Economic Geology Vol. 85, 691-713.

Schwartz, M. O., \& Surjono. (1990). Greisenization and Albitization at the Tikus Tin-Tungsten Deposit, Belitung, Indonesia. Economic Geology Vol. 85, 691-713.

Selley, R. C. (1976). An Introduction to Sedimentology. London: Academic Press.

Setijadji, L. D. (2011). New Insight on Granitic Rocks and Their Associated Metallogeny in Indonesia. Proceedings of the 1st Asia Africa Mineral Resources Conference 2011.

Soepriadi, K. B. (2014). Prospeksi Unsur Tanah Jarang (Rare Earth Elements) Daerah Kacang Butor dan Sekitarnya, Kecamatan Badau, Kabupaten Belitung, Provinsi Bangka Belitung. Bandung: Pusat Sumber Daya Geologi.

Suprapto, S. J. (2009). Tinjauan Unsur Tanah Jarang. Bandung: Pusat Sumberdaya Geologi.

Verdiansyah, O. (2006). Karbonatit: Petrologi dan Geologi Ekonomi. Yogyakarta: UGM.

Wentworth, C. K. (1922). A Scale of Grade and Class Terms for Clastic Sediments. The Journal of Geology, 377-392. 